\title{
A horogkereszt árnyékában I. \\ Horváth László Imre: Lett este és lett reggel vs. Trenka Csaba Gábor: Egyenlítői Magyar Afrika
}

\author{
Baka L. Patrik
}

\section{In the Shadow of the Swastika I.}

\section{Abstract}

The study focuses on the comparative analysis of the respective novels, Lett este és lett reggel (by László Horváth) and Egyenlítői Magyar Afrika (by Csaba Gábor Trenka). The chosen works are assessed while taking allohistorical classic literary textual horizons into account and analyzing their world building methods with a particular focus on their political and societal aspects, and how they relate to real world historical examples. The study, due to its size, is divided into two parts - the continuation will be available in the next issue of this journal.

Keywords: alternate history; allohistorical categories; historic analogies; contemporary references; national socialist ideology

Kulcsszavak: alternativ történelem; allohistorikus klasszisok; történelmi analógiák; kortárs áthallások; nemzetiszocialista ideológia

Subject-Affiliation in New CEEOL: Language and Literature - Studies of Literature

- Hungarian Literature

DOI: 10.36007/eruedu.2021.1.081-094

„- Hol születtél?

- Otthon, Magyarországon. És te?

- Itthon, Hungarovillben. Afrikában.

Összenevettünk."

(Lajtai Gábor és Pallag László;

Trenka Csaba Gábor:

Egyenlítöi Magyar Afrika; 90)

Az alternatív történelem talán legismertebb kutatója, Gavriel D. Rosenfeld szerint a történelmi emlékezet minden nép esetében megrajzolja azokat a legmarkánsabbnak tételezhetö töréspontokat, amelyek az adott nemzet szempontjából a 
leginkább válaszutaknak számítottak, s másként alakulásuk radikálisan eltérő jövőt eredményezett volna. Van azonban egy olyan világtörténelmi mozzanat, ami úgy fest, közel minden náció esetében dobogós - ha nem rögtön az első - helyen áll. Éppúgy a Rosenfeld primér kutatási területének számító amerikai alternatív történelmi regény esetében (Rosenfeld 2007), ahogy a magyar allohistorizmusnál (a jelen dolgozatban elemzett műveken túl ismert példái: Trenka 2013, 2017; Gáspár 2010; Green 2002; Thompson 2013), de a világ összes kontrafaktuális opusát összegyüjteni kivánó Uchronia.net adatbázisa szerint is ${ }^{1} \mathrm{ez}$ az esemény nem más, mint a második világháború, pontosabban annak eltérő végkimenetele: a Harmadik Birodalom győzelme.

Trenka Csaba Gábor Egyenlítői Magyar Afrika (Trenka 2010) és Horváth László Imre Lett este és lett reggel (Horváth 2014) címü regényeikben éppúgy ezt a kardinális múlthasadást választják alternatív univerzumuk kiindulópontjául, s megoldásaikban egymáshoz nagyon hasonló, a vizsgálat tárgyához közeledve mégis markánsan eltérő műveket alkotnak. Világépítésükben spekulatív fikciót, lélektaniságuk és nyelvük tekintetében pedig szépirodalmat, újabb remek példákat kínálva a kettő együttállására.

Jelen dolgozat a jelzett keretekböl adódóan komparatív tanulmány lesz, s a vizsgált opusok hasonlóságaira legalább annyira odafigyel majd, mint a különbözőségeikre is. A munkát terjedelmi okokból két részre bontjuk; a folytatás a folyóirat következő számában lesz olvasható. A dolgozat alább következő, első szakaszában az allohistorizmus klasszisai felöl nyitunk horizontokat a választott müvekre, majd alternatív világépítésük fonákjait vizsgáljuk, nagy odafigyelést fordítva a politikai és társadalmi világszerüségre - azaz az áthallásokra - és a valós történelemhez füződő analógiákra. Az elemzés interdiszciplináris és szövegcentrikus lesz, de részletesen kitérünk a zsáner és médiumközi kommunikációra is.

\section{Allohistorikus klasszisok}

Az alábbiakban a vizsgált regények tipizálását végezzük el Az alternatív történelem müfaja (Baka 2020, 139-142) címü dolgozatunk szempontrendszere szerint, amely felől a zsáner megannyi alkotása górcső alá vehető.

Mind Trenka, mind pedig Horváth regénye historikus kontrafaktumnak számít, tehát a mi világunk történelmét írja át egy meghatározó - ráadásul azonos - történelmi töréspont másként alakulásából bontva ki narratíváját és univerzumát. Innen nézve evidencia, hogy a múlthasadást megelőző események tökéletesen egybeesnek a mi világunk történelmével, kvázi azonos hivatkozási alapként szolgálnak a művek karakterei számára, mint a mi számunkra is. Fontos továbbá, hogy a kibontakozó alternatív univerzumok minden jelensége a mi világunkat jellemző realitás felöl is igazolható, tehát nem tartalmaznak semmiféle természetfeletti, varázslatos elemet - pusztán különös allohistorizmusnak számítanak.

A fenti vonatkozások egyértelmüvé teszik, hogy Karen Hellekson történelmi

1 A Hitler kulcsszó 156 összegyüjtött tételnél szerepel, kétszer annyiszor, mint a Napóleon. A vonatkozó listát lásd: Uchronia, Hitler (kulcsszó) = http://uchronia.net/bib.cgi/search.html?id=hitler 
szervezőelvek szerinti osztályozása értelmében mindkét mü a logikus ok-okozatisággal jellemezhető genetikus modellt müködteti, a múlthasadást kigeneráló véletlennel füszerezve, ami pedig mindenekelőtt az entrópikus modell sajátja (Hellekson 2001, 2-3). Fontos azonban megjegyezni, hogy a Lett este és lett reggel elbeszélő ideológusa, Klaus Arme épp a másik két helleksoni modell szerint magyarázza a világmindenség szervezödését, amikor a történelmi összefüggések céljáról értekezik - teleologikus modell - és determinista hitvallását igazolva a végső eseményeket állítja előtérbe - eszkatologikus modell. Arme sötét munkássága azonban csak egy szélsőséges ideológiát utólagosan alátámasztani kivánó elméletet eredményez, ami a regényvilágban sem nyer igazolást. Trenka müvében egészen más a helyzet, hiszen mint látni fogjuk, ő jószerével egybemontírozza a nácik tevékenységét az „ideát” megismert Szovjetunió működésével, jószerével ugyanazokat az eredményeket - s ami még fontosabb -, eseményeket generálva ki, univerzumának müködése szempontjából azt érzékeltetve, hogy az egyes történelmi mozzanatok így is, úgy is végbementek volna, bármelyik ideológia kerül is ki győztesen a világháborúból. Mintha a történelemnek célja volna - teleologikus modell -, és sorsszerüen szerveződne - eszkatologikus modell. Az Egyenlítői Magyar Afrika tehát, úgy tünik, képes egybemontírozni mindazt, amit Karen Hellekson elkülöníthetőnek, sőt osztályozási szempontnak vél.

A dolgozatunk bevezetőjében hivatkozott Rosenfeld elsősorban három vizsgálati horizont felöl véli megközelíthetőnek az egyes uchróniákat. Az egyik jószerével az, amit a bevezetőnk első bekezdésében tárgyaltunk, hogy milyen pozíciót foglal el a választott nexuspont a regényt író szerzők nemzeti történelmében. A második világháború másként alakulása egyértelműen a legkedveltebb témának számít a magyar alternatív történelmi kánonon belül, melynek legalább az egyharmadát, de szigorúbban vonva meg a zsáner kereteit, majdnem a felét ezek a regények jelentik. A második világégés kétségkívül a magyar történelem egyik sarokköve - ahogy az egész világé is -, Trenka és Horváth a magyar nemzetnek azonban teljesen más jelentőséget tulajdonítanak regényeikben. Előbbi magyar hősök horizontjából bontakoztatja ki narratíváját, magyar földön, részleges magyar revízióval, sőt a magyar gyarmatositás lehetőségével kecsegtetve, igaz, végül recesszióba bukva. A Lett este és lett reggel esetében viszont a magyarság marginális, sőt a náci ideológia számára idővel egyenesen megoldandó problémává válik. A könyv nem szerepeltet magyar hősöket, $s$ alig akad néhány bekezdés, amely magyar vonatkozásokkal bírna, ezzel is érzékeltetve nemzetünk jelentéktelenségét univerzumában. Mindez persze nem jelenti azt, hogy a trenkai magyar állam bármilyen komolyabb jelentöséggel bírna az alternatív világpolitika színpadán.

Rosenfeld másik két szempontja esetünkben egymásból bomlik ki és egymás felöl lesz magyarázható, a két regénynél azonban más-más módon. A Lett este és lett reggel egyértelmüen disztópia, mely pozíciót csak erösíti, hogy mind a magyar, mind Európa bármely más nációja, sőt a győztes németség szempontjából is az, még ha a világ átformálására felesküdött ideológiai gépezet maradéktalanul el is éri általa a célját. Barcsi Tamás disztópiákról értekező munkája (Barcsi 2011) értelmében Horváth univerzuma egy totális elnyomáson alapuló félelemrendszer, amely egy szélsőséges politikai eszmeiségen, a nemzetiszocializmuson és 
annak fajelméletén alapul. A müben olvasható naplóbejegyzések viszont a jelenig terjednek, a Gestapo pedig mindinkább használni kezdi az internetes totális ellenőrzés adta lehetőségeket is, a Barcsi által variációnak nevezett disztópiatípussá alakulva át, amely az ideológiaalapú megfélemlítést a technikai manipulációval vegyíti, ezáltal Orwell 1984-ének Nagy Testvérét idézve meg. Az alternatív világban a magyarságnak semmiféle haszna nem származik a náci győzelemböl, sőt maga is áldozatává válik a horogkeresztes gépezetnek, ilyenformán a regény visszatükrözi azt a kortárs, humánus világlátást, miszerint a nemzetiszocialisták győzelme egy sötét, örült jelent eredményezett volna - ez a válasz arra a rosenfeldi kérdésre, hogy miként viszonyul az alternatív világ a szerző korának illetve országának történelemszemléletéhez?

Trenka esetében nem ilyen egyértelmü a döntés, hiszen az Egyenlítői Magyar Afrika világa se nem jobb, sem pedig rosszabb annál, amilyen a mi univerzumunk huszadik századának második fele volt. Egy bipoláris világ, ahol a szabadság áll szemben a korlátoltsággal. A nácik természetesen elkövetik a számlájukra írható bűnöket, de Hitler lemondásával és a birodalom konszolidálásával nem folytatják az ideológia által megkövetelt tisztogatást. Sőt, a kortárs radikális jobboldal nacionalizmusa számára még jobbnak is tünhet a trenkai univerzum, elvégre a magyarság nagyobb ráhatással bír a világra - vagy egyszerübben fogalmazva, nagyobb államtesttel rendelkezik. Az afrikai őslakosok mindennapjai persze semmivel nem válnak ezáltal jobbá; számukra voltaképpen mindegy, hogy a brit, francia, belga és portugál gyarmatositók helyét magyarok, románok, németszlovákok és németek veszik át, elvégre mindkét szövetségi csoport a maga nemében arisztokratikus fölénnyel viszonyul hozzájuk, az évtizedek alatt éledező helyi nacionalizmus pedig úgyis menthetetlenül léket üt az idegen, s egyre gyengülő adminisztráción. Az Egyenlítői Magyar Afrika világa tehát más, mint a miénk, és mégis ugyanaz, s csak nemzeti nézőpont kérdése, hogy jobbnak, netalán rosszabbnak tűnik, hiszen ami az egyik oldalon (magyar) nyereség, az a másikon (francia) veszteség, a harmadik felöl nézve pedig érdektelen változás.

Az alternatív Harmadik Birodalom történelmi megítélését esetünkben a Szovjetunióra vonatkozó értelmezéseink felöl kell szemlélni, előbbi ugyanis „odaát” az utóbbi helyét veszi át, és nem önmaga démoni tébolyát nevelgeti tovább. A kommunista diktatúra negyvennégy évének negatívumai esetünkben a Náci Birodalom negatívumai, nem rosszabbak, de nem is jobbak annál; az alternatív trenkai világ tehát csak annyira disztópia, amennyire a mi kelet-európai múltunk is az.

A különös historikus uchróniák esetében nagyobb figyelmet lehet fordítani a nexuspont sajátosságaira is. A kellő precizitással kidolgozott kontrafaktumokról elmondható, hogy a múlthasadás nem divergencia ${ }^{2}$ (Rosenfeld 2007, 151) vagy neuralgikus pont (H. Nagy 2009, 26), hanem e kettő, mint közelkép és nagytotál viszonyul egymáshoz. A divergenciapont alatt bármiféle, mindennapinak mondható eseményt érthetünk, ami a történelem menetének alakulására első ránézésre kisebb ráhatással bír, ám olyan dominóeffektust indít el, melynek sokadik mozzana-

2 Noha a magyar szakirodalom átvette a Szélpál Lívia fordításában szereplő divergáló pont formát, szerencsésebbnek tűnik a divergenciapont használata, mivel nem maga a pont divergál. Az észrevétel Mekis D. Jánostól származik. 
ta a világtörténelem tekintetében már radikális változást, neuralgikus pontot eredményez. Az Egyenlítői Magyar Afrika divergenciapontja az, hogy a vízválasztónak bizonyult sztálingrádi csatát nem Paulus tábornok, hanem Ernst Rommel vezényli, tehát kvázi az ő kinevezése a töréspont. A Lett este és lett reggel szinte ugyanezt játssza meg: Horváthnál a Hitlerhez végletekig hü - másként szólva, a Führerétől eltérö, önálló döntésre nem hajlamos - Paulus halálos autóbalesetet szenved, a helyére pedig a franciák fölött győzedelmeskedő Erich von Manstein kerül. Rommel Trenkánál megnyeri, Manstein Horváthnál pedig a parancs ellenére elkerüli a sztálingrádi csatát, ami mindkét esetben ugyanazt a hosszú távú eredményt, neuralgikus pontot hozza magával: a nácik legyőzik a Szovjetuniót és megnyerik a világháborút. ${ }^{3}$

A múlthasadás jellege mindkét mü esetében politikai, hiszen egy hadászati eredmény változtatja meg a világtörténelem alakulását, ami hamar radikális társadalmi átalakulásokat hoz magával.

Erősségüket tekintve a két allohistorikus mü nem rendelkezik azonos tulajdonságokkal, amíg a Lett este és lett reggel ugyanis keményvonalas - másként hard - , addig az Egyenlítői Magyar Afrika kerettelenebb - azaz soft - uchrónia. A kettö különbségét jószerével az határozza meg, hogy milyen mennyiségben és mennyire pontosan használnak olyan történelmi szegmenseket - eseményeket, szereplőket, s akár utóbbiak jellemjegyeit -, amelyekből uchronikus jellegük adódik. Amíg tehát Horváth László Imre egyenesen halmozza ezeket a vonatkozásokat, addig Trenka Csaba Gábor inkább csak érzékelteti öket, és hátteret rajzol velük hétköznapibbnak, ha úgy tetszik, a Horváthéhoz képest emberközelibbnek számító narratívájához. A történetnek az allohistorikus világ ilyenformán csupán díszletét adja, ám ennek a dekorációnak igen mesterien kidolgozott minden apró íve, színe és repedése. Ahogy Takács Gábor fogalmaz: „,alternatív történelem, de az egész csak háttérül szolgál ahhoz, hogy a szerző elmondhassa, milyen is legbelül az ember, és hogy mi is az, ami igazán fontos az életben. A könyvben szereplő világ kínosan hasonlít a miénkre, minden baklövése a mi baklövésünk, minden nevetséges mozzanata minket tesz nevetségessé, bünei a mi büneink" (Takács 2009).

A parahistóriák mindezen felül osztályozhatók annak tekintetében is, hogy a történet hősei milyen társadalmi rétegbe tartoznak, másként szólva, saját életükön és mozgásukon túl bírnak-e bármilyen vezetői ráhatással a világpolitika s vele a világtörténelem alakulására. A mü karakterhorizontja továbbá azt is meghatározza, hogy az egyes regények elsősorban mely társadalmi osztály mindennapjait és közegét teszik érzékletesen átélhetővé. Horváth világa ebben az értelemben arisztokratikus - alakító - allohistória, hiszen föhőse és annak ismerősei is mindenekelött a vezető társadalmi rétegből kerülnek ki - „,a kiváltsagos Klaus által bejárt út mentén olyan részletességgel és alapossággal rajzolódik ki az alternatív múlt, ahogy az alulnézetet választó írók regényeiben sosem" (Zelei 2015, 78) -, míg Trenka regénye sokkal inkább népinek mondható, karakterei, még a bizonyos politikai pályát befutó föhőse is csak sodródnak az árral, elszenvedik a politikai hullámveréseket.

\footnotetext{
3 Ezen a ponton érdemes hivatkozni Everett sokvilág-elméletére, hiszen az egymáshoz relative közel álló trenkai és horváthi megoldások remekül érzékeltetik, hogy a mindennapok mozzanataiban is ott rejlö megannyi potenciális lehetőség milyen nagyszámú variánst eredményezhet, ha csak egyetlen apró szegmensüket módosítjuk is.
} 
Abból adódóan, hogy a Lett este és lett reggel naplóként, a trenkai regény pedig memoárként szerveződik, mindkét mü egyszerre fókuszál az alternatív idővonal múltjára és jelenére is, igaz, a mindennapjaink idejéhez közelebb eső jelen taglalására aránylag jóval kevesebb tér jut, mint a múltéra.

Összegzésként tehát elmondható, hogy mind Horváth, mind pedig Trenka regénye különös historikus alternatív történelem, s amíg az elöbbi a bevettnek mondható genetikus és entrópikus rendezőelv szerint szerveződik, addig az utóbbi a teleologikus és eszkatologikus modellektet is dinamizálja. Magyar szempontból mindkettő meghatározó, a mainstream történelemszemlélethez, illetve annak félelmeihez igazodó politikai múlthasadást választ - divergencia- és neuralgikus pontja értelmében is -, hiszen a sztálingrádi csata és a második világháború másként alakulása hazánk alternatív történelmére is nagyarányban kihat. A Lett este és lett reggel egyértelműen disztópia, az Egyenlítői Magyar Afrika azonban neutrális kontrafaktum. Erőssége szerint az elöbbi hard, karakterhorizontja értelmében pedig arisztokratikus, utóbbi azonban soft és népi, cselekményük pedig inkább a múltban, de részben a jelenben is játszódik.

\section{Világépítés, áthallások, ideológia}

Ha a második világháború sorsfordulóiról kérdeznénk egy történészt, a sztálingrádi csata vitathatatlanul dobogós helyen végezne, már csak azért is, mert a névadónak éppúgy presztízskérdés volt a város megtartása, ahogy az ostromlónak is szimbolikus értékkel bírt volna a bevétele - ezek a vonatkozások kétségkívül nagyban hozzájárultak ahhoz is, hogy a világégés egyik legnagyobb véráldozattal járó ütközetévé váljon (Harmat 2015). Egy alternatív történelmet író szerzőnek innen nézve adja magát, hogy ez a pont vagy kontrafaktuma alappillére legyen, vagy pedig annak felfüggesztése legyen számára megkerülhetetlen. A sztálingrádi ütközet azonban csak az alternatív világok leágazásának gócpontja. Lássuk, mivé és milyenné lett volna a világ, ha Rommel vagy Manstein veszi át Paulus helyét... két történész végzettségü alternativ történetíró tollából.

Az Egyenlítői Magyar Afrika szerint Hitlernek a győztes háborút követően sikerült konszolidálnia hatalmát, s az az Afrika, mely a világégés alatt is jórészt a szövetségesek gyarmata volt, immár a tengelyhatalmak és pribékjeik martalékává vált. Magyarországnak ilyenformán az ősi kontinens Egyenlítő által érintett, nyugati partvidékén, a mai Nigéria és Kamerun térségében juttattak területeket, „Német-Algériától” délre, az egykori Francia Egyenlítői-Afrika térségében, mely utóbbi a trenkai névadásban is szerepet tölthetett be. A gyarmat fövárosa Hungarovill, jellegzetesen magyar (Szt. István tér, Európai negyed, Óváros, s ide tartoznak az olyan helyi magyar átnevezések is, mint a Fekete-hegy vagy a Mária-öböl, s a Banántröszthöz vagy a Tisza Játék és Fegyvergyárhoz hasonló cégnevek), és - számunkra - kevésbé jellegzetes (Hitler sugárút, Szálasi körút) út-, utca- és városrésznevekkel.

A történelmi „örökségtöl” azonban nem lehet maradéktalanul elszakadni, hiszen az ugyancsak gyarmatosító románokkal például rendre meg-megújuló határkonfliktusok követik egymást. Ilyen az az ironikusan összefoglalt '67-es eset is, amikor: 
[A] szörös rómaiak [...] [m]ár megint elfoglaltak a Niger mellett néhány ültetvényt tölünk, azon az alapon, hogy az a Daciából érkezett római legionáriusoké volt Vespasianus császár idején (Trenka 2010, 54, 53).

A történelmi visszaemlékezések sosem esetlegesen, hanem valami fontos, de mindennapi mozzanat apropóján bontakoznak ki. Ilyen például az 1967. december 17ei dátum, Hitler halála, amikor is a propagandát erőteljesen kiaknázó emlékfilm a Führer életének és a birodalom történetének számos sarkalatos eseményét eleveníti fel, például a „,hihetetlenül véres” 1941-43-as oroszországi hadjáratot, amely a kommunista, szláv „,hordák” bukásával végződött, ám a nagyarányú veszteségek fényében Hitler felhagyott a további terjeszkedéssel. 1947-ben fegyverszünetet, késöbb pedig békét kötött az angolszászokkal. A Führer hatalomból való visszavonulása 1954-re datálható, amikortól a hivatalos információk szerint a fasizmus elméleti továbbgondolása kötötte le az energiáit, de mint a főhős, Lajtai Gábor nagyapjától megtudjuk, inkább volt érte felelős az első agyvérzése. Hitler visszavonulását követöen a hatalmat annak helyettese, Walter Eicker örökli, aki a mi univerzumunkban ismeretlen figura, „odaát” azonban az ő nevéhez füződik az internálótáborok fokozatos felszámolása, az életben maradt zsidók Palesztinába történő kitelepítése ahol azok aztán az arabokkal szövetségben (sic!) hajtanak végre terrorista akciókat a gyarmatositókkal szemben -, a Gestapo befolyásának csökkentése, illetve annak a tárgyalássorozatnak a megkezdése, melynek fő terméke az angolszász-német atomfegyverek számának korlátozása volt. A világpolitika persze hullámzott, a várva várt enyhülést pedig folyton derékba törte valami sikertelen mozzanat, például „Németszlovákia" tengelyhatalmak általi megszállása vagy Dél-Franciaország csatlakozása az Angolszász Védelmi Közösséghez.

Utoljára 1965-ben láthatta szeretett vezérét a nép, a szokásos berlini díszszemlén. Legendás bajusza megőszült, fehér haját hosszúra növesztette. Bíborszinü keleti tógában állt az emelvényen, az új birodalmi divat szerint. Beszédet már nem mondott... (Trenka 2010, 53).

Az idézet hangsúlyozza az önkényuralmi rendszerek külsőségek iránti vonzódását, esetünkben például a római hagyományt - melyen a birodalom szimbolikája legalább annyira alapult, mint az északi mitológián - felújító náci divatot. Trenka regénye azonban nem fordít különösebb figyelmet az okkultizmusból táplálkozó ideológiák harcára vagy evolúciójára, ahogy azt Horváth müve teszi, ellenben egy igazán sajátos eljárással él. Valahányszor feltünik egy-egy sarkalatos alternatív történelmi esemény az Egyenlítői Magyar Afrika világában, az mindig egybeesik azokkal a történelmi mozzanatokkal, amelyek a mi világunk szovjet érdekszférába tartozó Kelet-Európájának múltbéli sarokköveit adják, legyen szó magyar vonatkozásban az '56-os forradalomról, a „Németszlovákiában” éledező emberarcú „,nemzetiszocializmusról” és annak '68 augusztus végén történt leveréséről, vagy akár a rendszerváltásról és a parlamentáris demokrácia bevezetéséről, amely „odaát” értelemszerüen nem Gorbacsov, de Heidrich - a mi világunkban Eickerhez ha- 
sonlóan ismeretlen karakter, nem összetévesztendő a Cseh-Morva Protektorátus véreskezű helytartójával, Reinhardt Heydrichhel - nevéhez föződik, idejét tekintve ugyanakkor. Az '56-os forradalom után a mi világunkban hatalomra került Kádár helyét Trenkánál Németh Árpád tölti be, aki éppúgy ambivalens figuraként, a „gulyáskommunizmushoz" hasonló rendszert megteremtve állt az ország élén; a következő szakasz néhány terminus felcserélése után mindkettejük jellemzéseként felfogható:

Nem tudom, hogy Németh Árpád egy buta demokrata volt-e, aki kényszerüségböl fasisztát játszott, vagy vérbeli fasiszta, aki a hatalom megtartása érdekében néha liberális pózban tetszelgett. A hazaárulást, aminek hatalmát köszönhette, nem menti egyik változat sem. Még vicc is született az ö, és vele egyetemben egész Magyarország mélységes skizofréniájáról: mást mond Árpád, és mást a Német (Trenka 2010, 168).

A fekete és vörös tömb egybeesését az idő elörehaladtával mind markánsabb gazdasági recessziójuk éppúgy továbberősíti, ahogy a propagandagépezetük, ${ }^{4}$ cenzúrájuk, a politikai fősodortól eltérő véleményű rétegek háttérbeszoritásáért tett törekvéseik, a magtól távolabb eső territóriumaikról való kihátrálásuk vagy kiveretésük, és a hatalmat egymástól megöröklö, azonos generációhoz tartozó vezetöik - „ideát” olyan pártfőtitkárok mint Andropov és Csernyenko, „odaát” pedig olyan Führerek mint Ribbentrop vagy Ernst Raffe - gyors halálozási rátája, s az ebböl fogant groteszk vicchagyomány is. ${ }^{5}$ Az egyre erősödő háttérbeszorulást jól szimbolizálják az Afganisztánban elesett német katonák sírkövei, melyek eleinte még kőböl, aztán fából, végül azonban már csak gallyakból összedrótozott tákolmányok voltak; a keleti államban trenka Harmadik Birodalma éppolyan értelmetlennek bizonyult háborút vivott, mint „ideát” a Szovjetunió, s a két konfliktus időszaka is egybeesik. A magyar gyarmaton az elvtárs helyett a testvér terminust használják, az általunk ismert KISZ (Magyar Kommunista Ifjúsági Szövetség) helyét a FISZ (Magyar Fasiszta Ifjúsági Szövetség) veszi át, az MSZMP-ét (Magyar Szocialista Munkáspárt) az MSZFMP (Magyar Szociálfasiszta Munkáspárt), ám a Szabad Európa Rádió tevékenysége ugyanarra irányul. A Vezér halálakor sugárzott film néhány képsor erejéig a legyőzött szovjet rendszer borzalmaira hívja fel a figyelmet, kihangsúlyozva, hogy Hitler „sírt”, amikor megmutatták neki a kommunista haláltáborok hullahegyeit. Az alternatív világban a Végső megoldás jószerével a rendszerváltásig államtitok marad, s csak a sztálini terror gulágjainak borzalmai számítanak történelmi ténynek. Az áthallás itt is zavarba ejtő, hiszen ,ideát” a vörösök voltak azok, akik alig győzték hangoztatni a nemzetiszocialisták rémtetteit, amelyektöl ök maguk szabadították meg a világot. Továbbá nem hiábavaló megjegyezni azt sem, hogy a mi síkunkon

4 „Az olvasókönyvünkben az van, hogy Hitler nagyon szerette a gyerekeket meg a népet, és állandóan csak rájuk gondolt" (Trenka 2010, 60). 1953-ig a mi világunk történelemkönyvei is bövelkedtek hasonlóan mély szentenciákban.

5 „A 60-as évek gyarmati magyar szociálfasizmusa tehát egyfajta látszatkonjunktúrát él meg, miközben az egész rendszer alapvetően nagyon beteg. Egy párhuzamos univerzum alternatív történelmének ideológiai árkai mentén álldogálva itt is elmondható, hogy míg a Nyugat haldoklik, a »mi rendszerünk“ - Hofival szólva - eleve halva született" (Horváth 2014). 
az USA és a Szovjetunió alkotta pólusok ${ }^{6}$ mindössze egyetlen dologban voltak egy szintre hozhatók, az pedig az atomprogram; a bolygó elpusztításában mindketten azonos hangsúllyal vehettek volna részt, rugalmasság, kultúra s fejlődés terén viszont igen távol álltak egymástól. Nincs ez másként Trenka univerzumában sem - a világégés utáni időszakot a hidegháború fagyos szele járja át:

A németeknek elég atombombájuk van ahhoz, hogy az USA ne merjen megtámadni bennünket [...]. Az amerikaiaknak meg ahhoz van elég bombájuk, hogy a németek ne merjék megtámadni öket. És ez összesen éppen annyi, hogy bármikor, akár véletlenül is, kirobbanthatják a lábunk alól a bolygót (Trenka 2010, 102).

Trenka érvelése egyszerü: nincs az a gátakkal és korlátokkal terhes diktatúra, amely versenyképes párja lehetne egy szabad demokráciának. És miként is volna ez jobban ábrázolható, mintsem egy „,igazi Super Riffle” szenzációnak számító megjelenésével, amit a főhős, álítása szerint egy évtizeden át nem volt hajlandó semmi másra lecserélni. Gyalai Zsófia remek összegzésével szólva: „Az Egyenlítői Magyar Afrika minden fikciójával együtt is szivfájdítóan realisztikus összefoglalása a magyarság XX. századi történelmének, és azt a nyugtalanító gondolatot ébreszti az emberben, hogy bárhogy is alakult volna a világégések kora és az utána következő pár évtized, nekünk sosem lett volna fenékig tejfel az élet" (Gyalai 2012). A Trenka-mű a rendszerváltásig vezető úttal, s a kelet-európai közegre rászakadt szabadságérzéssel szembesit, a '60-as években született generáció által megélt tapasztalatoknak állítva alternatív görbe tükröt, minek folytán lélektani korlenyomatként is forgatható (Mezei 2010).

Az Egyenlítői Magyar Afrika világában bár a központi hatalmak győztesek voltak, balkáni szövetségeseik, illetve Magyarország és a Trenkánál „Németszlovákiaként” emlegetett Szlovákia érdekei végig egymással szemben álltak, háborús érdemeiket pedig mindahányan a világégést követő osztozkodásra gyüjtögették; nem volt ez másként „ideát” sem. Kiderül azonban, hogy Hitler ráhatása révén kényszerbéke fogant a Kárpát-medencében, a magyar revizionisták viszont éppúgy elégedetlenek vele, mint minden más környékbeli náció. Ugyancsak Lajtai nagyapjától tudjuk meg, hogy Erdélynek is csupán egy része - a második bécsi döntés értelmében Észak-Erdély - került vissza Magyarországhoz, az ő szülővárosa például nem, s az idősödő férfi kifejti, évtizedek után is „ölni tudna azért a földért”. Főhősünkben ez a gondolat egy másikkal, a túlfütött nacionalizmus müködéséböl levont tapasztalattal vegyül $^{7}$, miszerint nincs az az elnyomó társadalom, amely biztonságban érezhetné magát az elnyomottak földjén:

6 Csak a regény legvégén jelenik meg opcióként a többpólusú világ potenciális kialakulása Kína emlegetésével, melyet „odaát” elkerült a kommunista ideológia.

7 A faji, nemi, nemzeti vagy szexuális irányultságú diszkrimináció, az elrugaszkodott nacionalista mellveregetés, illetve az álkultúrfölény hangsúlyozása mindig számíthat elbeszélönk rendszerbontó kritikájára - „Fölöttébb utáltam olyasmibe belekeverni a zsidókat, a hottentottákat és a sárkányrepülőket, amihez valójában semmi közük" (Trenka 2010, 168) -, ahogy az Országház csúcsán ékeskedő trikolór nyilaskereszt, a Győzelem Napjává keresztelt, összevont nemzeti ünnep, azaz március idusának patetikussága is, de éppúgy határozott véleménye van a vörös szintől irtózó Szálasiék azon ötletéröl, hogy talán jobb lett volna fekete-fehér-zöldre cserélni a nemzeti trikolórt. Mindez azt mutatja, hogy Lajtai Gábor mindenekelőtt humanista és realista gondolkodású elbeszélő. 
[M]i lesz, ha egyszer a négerek is úgy érzik majd, hogy ölni tudnának, mondjuk, azért a földért, ahol Hungarovill épültt[?] [...] Rendben, a magyar harangok szavát értem. De akkor mit jelent a román harangok hangja? És a néger harci doboké? És az angol, meg a német, meg a francia harangoké? Nem is szólva a kínai csatagongokról meg az amazóniai indiánok lábszárcsont kopogóiról? Attól félek, Hemingway egy jó szándékú, csendes barom, mert soha nem értünk, hanem ellenünk szólnak a harangok (Trenka 2010, 97).

Feketék és feketék viszonyát tekintve az az időszak, ami a mi világunk amerikai polgárjogi mozgalmával, vagy talán még inkább a Dél-afrikai Köztársaság apartheid politikájával fémjelezhetö, a magyar gyarmaton is hasonló jegyeket ölt, a tapasztalat pedig az, hogy alapvetően a fehérek által müködtetett szegregáció tehető felelőssé a gyarmati feketék nacionalizmusának fokozatos felerősödéséért is.

A hetvenes években a hungarovilli bennszülötteknek már legalább a fele magyar keresztnevet viselt. Nevettünk, ha találkoztunk egy-egy ébenfekete bőrü Emesével, Csabával és Árpáddal [...]. A négerek soha nem értették, miért nem mehettek be a zárt éttermekbe és mozikba, miért nem szállhatnak fel a fehér autóbuszokra, amikor pedig a nevük már magyarrá tette őket (Trenka 2010, 124).

A kelet-európai államok alternatív gyarmatszerzése apropóján feltétlenül szükséges tennünk egy „ideátra” vonatkozó kitérőt. Zeidler Miklós Honvéd áll a Kilimandzsárón? Egy különös beadvány a Külügyminisztérium irattárában (Zeidler 2014) címü tanulmánya igen egyedi horizont felöl közelít rá a Magyar Országos Levéltár anyagára, föként pedig az 1920-30-as években a Külügyminisztériumhoz eljuttatott különböző tárgyú, töredékes, javarészt laikusok által irt levelek alkotta 57. csomóra. Ennek egy igen izgalmas darabját képezik Pósa Endre tervezetei, melyekben nyolc közép-európai állam számára hozna létre - Trenka müvéhez hasonlóan - gyarmatokat Afrikában, elsősorban az azok túlnépesedéséből adódó problémák, illetve a köztük húzódó feszes viszony meg- és feloldására. Pósa úgyszólván a lakosság-lecsapolásban látja a kiutat. Felosztása szerint „Magyarországé lett volna egész Tanganyika - és talán Zanzibár és Pemba szigete is, bár ez nem derül ki egyértelműen [...]. A Pósa által mellékelt térképen a pán-közép-európai unió [az említett nyolc közép-európai állam idealizált szövetségi rendszere] számára kijelölendő zóna észak-déli irányban mintegy 2800 km, kelet-nyugati irányban jó 1000 km kiterjedésü, a teljes terület tehát közel 3 millió km². Az elképzelt »Magyar Kelet-Afrika« - az 1920 óta brit igazgatás alatt álló Tanganyika mandátumterület középső része - észak-déli irányban kb. 350 km, kelet-nyugati irányban bő 1000 km kiterjedésű volt, összesen tehát közel 400 ezer km², az anyaország területének négyszerese" (Zeidler 2014, 351). A Trenka-, illetve a Pósa-változat közti legszámottevöbb különbséget a magyar gyarmat Afrikában történő nyugati (Trenka) és keleti (Pósa) elhelyezése adja. És persze az, hogy amíg az előbbi a második világégés eredményeként tünteti fel azt, addig az utóbbi elképzelése igencsak idealizált, ugyanis a gyarmati rendezést csupáncsak a már említett túlnépesedés apropóján követné el, egy pillanatig sem számolva az érintett hatalmak ellenállásával, lévén 
tervét logikusnak és indokoltnak értékeli. Ahogy azt Zeidler is megjegyzi, az sem bizonyos persze, hogy Pósa tervezetei valaha is eljutottak Kánya Kálmán külügyminiszterhez, ,,[a]z azonban tény, hogy Pósa levelére ismeretlen kéz felírta: „ad circulandum« és »Pol. oszt. (szórakoztatásul)« - s talán épp a külügyminiszter volt az, aki ilyen ajánlással köröztette a küldeményt közeli kollégái között. Kánya szarkazmusát és vitriolos iróniáját ismerve ezt nemcsak lehetségesnek, hanem egyenesen valószínünek tartjuk [...]. Mindenesetre tény, hogy Kánya sem a »Pán-Közép-Európa“ eszmét, sem a kelet-afrikai magyar gyarmatosítás koncepcióját nem építette be külpolitikájába" (Zeidler 2014, 353).

Zeidler Miklós tanulmányában Pósa tervezetét egy hasonló ihletésű szöveggel rokonitja, mégpedig Paikert Alajos Germán-Turán Államszövetség című felvetésével, melyet a szerző egyenesen gróf Tisza István miniszterelnökhöz juttatott el 1915 nyarán. Mint azt Zeidler írja: „Ennek az Európa és Ázsia nagy részére kiterjedő konföderációnak (?) a keretében - a remélt háborús győzelem esetén - Magyarország területeket szerzett volna Dalmáciában, Bosznia-Hercegovinában és Szerbiában (esetleg Romániában és Besszarábiában is), Albánia élére pedig magyar fejedelem került volna, s nem maradt volna el a gyarmati terjeszkedés sem: Észak-Afrikában Barka (az ókori Cirenaica), Kelet-Afrikában Szomália, Nyugat-Afrikában pedig Francia-Kongó északi része lett volna magyar külbirtok" (Zeidler 2014, 353). Látható tehát, a magyar államiság akár tengereken és óceánokon is átívelő kiterjesztése nem csupán az írói fantáziát ihlette meg.

A Lett este és lett reggel első naplóbejegyzése 1942. június 13-án, Friedrich Paulus halála után íródik, akinek helyére Erich von Manstein kerül. Az ekkori feljegyzések még maradéktalanul megfelelnek a mi világuk történelmének, majd a dominóeffektus révén a két idősík mind távolabb kerül egymástól. Horváth innen nézve hasonlóan jár el, mint az Andrew Roberts szerkesztette Mi lett volna, ha...? (Roberts 2006) címü kötet történész szerzői, akik nagy odafigyeléssel, sokszor alig észrevehetöen szövik bele a történelembe az alternatív történelmet. A könyv szovjet bukásra is koncentráló fejezetét Simon Sebag Montefiore jegyzi, melynek címe ...Sztálin elmenekül Moszkvából 1941-ben? (Montefiore 2006). Az önreflexiókkal és áthallásokkal is nagyarányban operáló írás felvázolja az emlegetett időszak hadászati helyzetét s azt a Moszkvát, amelyet csak Sztálin jelenléte, és az abból eredeztetett rettegő morál védhetett volna meg a náciktól. A gazda azonban Montefiore esszéjében távozott, minek okán a védelem is összeomlott, Zsukov pedig kénytelen volt a városon túlra vonulni. A dolgozat ezt követöen egy, az általa is előszeretettel működtetett kirakatperben ítéli halálra Sztálint.

Horváth világában éppúgy sor kerül egy tábornoki összeesküvésre, de már Sztálingrád eleste után, a kommunista fővezér pedig egy kettétört mutatópálcával a szemében fejezi be földi pályafutását. Manstein a Lett este és lett reggel univerzumában megkerüli Sztálingrádot, és szétveri a Volgán túl gyülekező négy orosz hadsereget, eldöntve a háború kimenetelét. Az oroszok az Urálon túlra szorulnak az attól nyugatra eső területek pedig a német Lebensraum, azaz az élettér részévé válnak -, a békediktátum értelmében átadva teljes hadiiparukat, és megszakitva minden diplomáciai kapcsolatukat az USA-val. Ezt követöen folyamatosan elesik Málta, Gibraltár, majd sikerül felszámolni a Lebensraum mocsaraiban egyesült, 
Fjodorov és Kolpak vezette hatalmas orosz partizánhadseregeket is, Arme révén Caesar alesiai csatánál kivitelezett stratégiáját alkalmazva. Itt jegyezzük meg, hogy az élettér kitágítása jelen esetben nem pusztán a szláv lakosság elüzésével vagy lemészárlásával, s a németség betelepítésével jár, hanem a „tipikus germán természeti környezet, növényvilág elterjesztésével" is, jól stilizálva egy olyan folyamatot, amit valamely szélsőséges szemlélet hozhatna magával, ha kiapadhatatlan forrásokkal rendelkezne.

Trenkánál csak az alternatív hidegháború szele járja át a világot, Horváth azonban nem riad vissza az atomtól: az USA végső kétségbeesésében mind az öt töltetét ledobja a náci Európára, de így sem sikerül megtörnie a birodalmat, sőt csak azt éri el, hogy a legnagyobb kárt szenvedett franciák a nácik elkötelezettjeivé válnak. A támadássorozatban Berlin is elpusztul, a főváros bukása után a pragmatikus vaskabátosok azonban hozzáfognak a Germánia nevű világfőváros építéséhez, Albert Speer ismert tervei szerint - utóbbi polisz a címadója G. L. Thompson-regénynek is (Thompson 2013). Hitler halálos fenyegetéseinek gyümölcseként végül a horogkeresztes nukleáris rakéták is elkészülnek. Talán itt érdemes megjegyezni, hogy mindkét elemzett univerzumban kiemelten fontos a Holdra szállás körüli ürverseny, ami az Egyenlítői Magyar Afrikával ellentétben Horváthnál a nácik dicsőségét hozza el.

Hitler halála után a führeri pozíció a Lett este és lett regge/ világában szimbolikus státusszá válik, a második vezérré kinevezett Fegelein esetlenségével felerösitve, a birodalom irányítását pedig a náci elitet csoportosító Szindikátus, egyfajta birodalmi nagytanács veszi át. Az USA időközben megosztottá válik, kettészakad, ahol a Dél, radikális történelmi hagyományait felelevenítve átveszi a náci fajelméletet, munkatáborokat létesit a fekete rabszolgák és a politikai foglyok számára, s a Harmadik Birodalom jóváhagyásával offenzív politikát folytat mind Mexikó és Kuba ellen; lassanként nemzetiszocialista világ alakul. Ehhez hozzájárul, hogy a harmadik Führer William Patrik Hitler lesz, aki félig angolként lehetővé teszi a két nép egyesülését. Az ő uralmát követően pedig már nyitott az út az Arme-ház végső fölemelkedése előtt. Erich Arme egyfajta tévésztárként, az új Siegfriedként láttatja magát, aki a holdbázisról megindított, kiterjedt és bénitó támadása révén Caesar módjára rohanja le saját Galliáját, Észak-Amerikát. Számára talán már nyitott az út más világok és a halhatatlanság felé is.

A regény egyik legmarkánsabb világépítési eleme az újabb dimenziókkal ellátott auschwitzi koncentrációs tábor, amely a végső megoldás után mindig újabb és újabb foglyokkal, föként szlávokkal telítődött. Amikor Klaus Arme meglátogatja, hárommilliós (sic!) lélekszámmal bír, és az áltatás ördögi szintjének kifejeződéseként Reményvárosnak nevezik. Mivel a vizitre csak a regény derekán kerül sor, a befogadó számára sokkolóan hat, amikor megtudja: az Arme-dinasztia tulajdonképpeni magánbirodalmáról beszélünk, mely ilyenformán az ingyenes rabszolgamunkán alapul. Reményváros a náci ipar egyik legfontosabb központja, a gyárakon túl pedig éppúgy részét képezik az alkalmazottak szépséges lakóparkjai, mint a spártai nevelést felelevenítő SS Reichkinder kaszárnyái - utóbbiak lakói a markáns germán népességnövekedést megcélzó, ,,ideát” is elindított Lebensborn program államnak adományozott gyerekeiből kerültek ki (Németh 2006) - a „Vadászterülettel”, ahol 
időnként lemészárolhattak néhány rabszolgát, vagy a Donortábor elnevezésű szektor, amely a náci elit tagjai számára alkalmas, a szükséges szervátültetéshez bármikor használható egyének lakóhelye. A komplexumot Arme egyik ellenszónoka Európa rákjaként, s nem a jövőt megalapozó terhességeként azonositja, Mengele ott helyet kapó laboratóriumai kapcsán pedig megjegyzi: ha különböző fajokról lehetne beszélni, úgy a kísérleteknek semmilyen hasznuk nem volna a germánok számára. Mengele ugyanis már ekkor az ember tökéletesítését célzó kísérleteket folytat, melyek a náci múlt tanulmányunk következő részében kifejtésre kerülő „kutatásán” túl a birodalom markáns célját adják. Ennek egyik mellékterméke a nem árja népek különböző módokon való kiirtása: a lengyelek mellett a regény igazán szűk magyar vonatkozásai közül a legmarkánsabb az, amikor Himmlernek hála olyan, betegségmegelőző oltásként reklámozott vakcinát fecskendeznek a két ország minden lakosának vérébe, ami sterilizálja a népességet (sic!). Ennyiben voltaképpen le is zárul az alternatív univerzumban elképzelhető magyar ,,jövő”. De a célul kitüzött náci faji fejlődés a szöveget jelentő Arme-napló utolsó bejegyzésekor csak egy rémisztő ambivalenciáig jut el: külsőségeiben hibátlan, atlétikus, szőke és kék szemü árja, ám lelketlen vad, ami számára idegen bármiféle emberi érzelem, $s$ ami úgy veti meg a gyengeséget, hogy vele a gyengédség mibenlétét is elfelejti.

\section{Irodalom}

Baka L. Patrik (2020): Az alternativ történelem müfajai. Fórum Társadalomtudományi Szemle, 2020/3, 129-150.

Barcsi Tamás (2011): Spekulációk a szabadságról - Negatív utópiák. In: Keserü József H. Nagy Péter (szerk.): Kontrafaktumok. Spekulatív fikció és irodalom. Komárom: Selye János Egyetem Tanárképzö Kara, 49-75.

Everett, Hugh III. [é.n.]: The Many-Worlds Interpretation of Quantum Mechanics - The Theory of the Universal Wave Function (doktori disszertáció) = http://www.pbs.org/wgbh/ nova/manyworlds/pdf/dissertation.pdf

Gáspár László [L. G. Gaspars] (2010): Mi, I. Adolf. Budapest: Fapadoskönyv.hu.

Green, W. Hamilton [Galántai Zoltán] (2002): A negyedik birodalom. Budapest: Valhalla Páholy.

Gyalai Zsófia (2012): Trenka Csaba Gábor: Egyenlítői Magyar Afrika. Sci Art = https:// sciart.eu/hu/2012-07-16-0807/37/trenka-csaba-gabor-egyenlitoi-magyar-afrika

H. Nagy Péter (2009): Imaginárium IX. SF: A képzelet mesterei. Opus, 2009/2, 23-32.

Harmat Árpád Péter (2015): A sztálingrádi csata, a történelem legnagyobb ütközete. Történelem cikkek = http://tortenelemcikkek.hu/node/154

Hellekson, Karen (2001): The Alternate History: Refiguring Historical Time. Ohio - London: The Kent State University Press.

Horváth Krisztián (2014): Egyenlítöi Magyar Afrika. Nyelv és Tudomány = https://m.nyest. hu/hirek/egyenlitoi-magyar-afrika 
Horváth László Imre (2014): Lett este és lett reggel. Budapest: Magvető.

Mezei Attila (2010): Trenka Csaba Gábor: Egyenlítői Magyar Afrika. Ekultura = http:// www.ekultura.hu/olvasnivalo/o/cikk/2010-04-15+00\%3A00\%3A00/trenka-csaba-gabor-egyenlitoi-magyar-afrika

Montefiore, Simon Sebag (2006): ...Sztálin elmenekül Moszkvából 1941-ben? In: Andrew Roberts (szerk.): Mi lett volna, ha...? [fejezetek a meg nem történt világtörténelemböl]. Budapest: Corvina, 125-142.

Németh István (2006): Lebensborn. Az Életforrás egyesület. Rubicon, 2006/10, 25-27.

Roberts, Andrew (szerk.) (2006): Mi lett volna, ha...? [fejezetek a meg nem történt világtörténelemböl]. Budapest: Corvina.

Rosenfeld, Gavriel D. (2007): Miért a kérdés, hogy „mi lett volna, ha?” Elmélkedések az alternatív történetírás szerepéröl. Ford. Szélpál Livia. Aetas, 2007/1, 147-160.

Takács Gábor [Acélpatkány] (2009): Egyenlítői Magyar Afrika. Fiction Kult = http://fictionkult.hu/cikk/egyenlitoi-magyar-afrika-295

Thompson, G. L. [Gráczer László] (2013): Germánia. Budapest: Kossuth.

Trenka Csaba Gábor (2010): Egyenlítői Magyar Afrika. Budapest: Agave Könyvek.

Trenka Csaba Gábor (2013): Place Rimbaud. Budapest: Syllabux.

Trenka Csaba Gábor (2017): La Grande Image. Budapest: Syllabux.

Uchronia (online alternatív történelmi gyüjtöfórum) = http://uchronia.net/bib.cgi/search. html?id=hitler

Zeidler Miklós (2014): Honvéd áll a Kilimandzsárón? Egy különös beadvány a Külügyminisztérium irattárában. In: Manhercz Orsolya (szerk.): Historia critica. Tanulmányok az Eötvös Loránd Tudományegyetem Bölcsészettudományi Karának Történeti Intézetéből. Budapest: Eötvös Loránd Tudományegyetem, 343-356.

Zelei Dávid (2015): Részletek a Faust család naplójából. Horváth László Imre: Lett este és lett reggel. Opus, 2015/2, 73-79. 